\title{
The Problem of Glutathione Determination: a Comparative Study on the Measurement of Glutathione from Plant Cells
}

\author{
Péter Hajdinák , Ádám Czobor¹, Tamás Lőrincz¹, András Szarka* \\ ${ }^{1}$ Department of Applied Biotechnology and Food Science, Laboratory of Biochemistry and Molecular Biology, \\ Budapest University of Technology and Economics, H-1111 Szent Gellért tér 4. Budapest, Hungary \\ *Corresponding author, email: szarka@mail.bme.hu
}

Received: 06 December 2017, Accepted: 01 February 2018, Published online: 26 February 2018

\begin{abstract}
The level and redox status of glutathione is a good indicator for the rate of oxidative stress and eco-toxicological injury in plant cells and subcellular organelles. Thus the determination of GSH and its redox status has special importance. A variety of spectrophotometric and HPLC methods are available to measure glutathione (GSH). The spectrophotometric DTNB-GSH recycling assay is specific due to the application of glutathione reductase, it is rather quick and easy to perform, not surprising that it is rather popular. In the present study we make an attempt to compare the DTNB-GSH recycling assay and the more sophisticated, but difficult monochlorobimane $(\mathrm{mBCl})$-HPLC method to choose the one that best suits for eco-toxicological and plant stress investigations. We found that the acidification by sulphosalicylic acid (SSA) used for the stabilization of samples for DTNB-GSH recycling assay gives lower efficiency to this method than the formation of $\mathrm{mBCl}-\mathrm{GSH}$ fluorescent conjugate. The measurable GSH contents were lower in the case of DTNB-GSH recycling assay than in the case of GSH-mBCl conjugates determined by HPLC with fluorescence detection. The auto-oxidation could almost perfectly be prevented by the presence of $\mathrm{mBCl}$ in the organelle isolation buffer. Furthermore, this way the reduced GSH content of organelles could be determined much more precisely. However, it is worth to note that the application of $\mathrm{mBCl}$ significantly elevates the cost of GSH determination, especially in case of cell organelles.
\end{abstract}

Keywords

glutathione, plant cell, determination, HPLC, eco-toxicology, bimane

\section{Introduction}

Cadmium is a non-essential heavy metal, which can be found in both soils and waters as trace element [1]. Its concentration in unpolluted soils and sediments is generally between $0.01-1 \mathrm{mg} / \mathrm{kg}$ and in case of unpolluted seawater $0.01-0.1 \mu \mathrm{g} /$ litre $[2,3]$. However, due to anthropogenic activities the concentrations of cadmium significantly increased in the environment. These activities include zinc smelting, manufacturing of nickel-cadmium batteries, combustion of fossil fuel and waste incineration. Approximately 22000 tons of cadmium have been discharged into the environment between 1950 and 2000 $[4,5]$. Phosphate fertilizers also contain cadmium, therefore agricultural soils are at a certain level contaminated by cadmium all over the world $[1,2,6]$. Uptake of toxic amounts of cadmium has serious consequences for the plants. Most of them are related to the interaction of cadmium with carboxyl and thiol groups of proteins [7]. These toxic effects result in chlorosis, growth inhibition, stunting and root damage $[1,3,6,8]$.
To chelate metal ions plants synthetize two types of metal binding ligands: metallothioneins (MTs) and phytochelatins (PCs) [9]. PCs are a family of peptides, with a general structure of ( $\gamma$-GluCys) ${ }_{n}$-Gly. PCs have a clear role in chelation and vacuolar sequestration of cadmium $[1,10]$. PCs form chelates with $\mathrm{Cd}$, due to the thiol groups of Cys, and preventing it from existing as free $\mathrm{Cd}^{2+}$ in the cytosol [11]. PCs are synthetized non-translationally by PC synthase, located in the cell cytoplasm [1, 12, 13]. PC synthase requires reduced glutathione (GSH) as substrate for PC synthesis.

The glutathione pool of plant cells can be found mainly in its reduced (GSH) form $[1,8,14]$. GSH is involved in several biochemical processes such as storage of sulphur, regulation of transcription and translation, modulation of enzyme activity, modification and transport of different hormones $[15,16]$. As a member of ascorbate-glutathione cycle, it also plays an important role in the antioxidant defence system of plant cells. Since cadmium has a high affinity for thiol groups, glutathione can also act as a first 
line of defence against cadmium, by forming sulphide complexes, that can be transported into the vacuole [8]. A transient decrease in glutathione level can be observed in the presence of high amounts of cadmium due to PC synthesis and sulphide complex formation. Longer exposition to cadmium results in increased expression of genes of the GSH biosynthesis $[8,13]$. Thus GSH level can also function as a biomarker of metal toxicity, especially for cadmium $[6,13]$.

Therefore, the proper and precise determination of glutathione content of plant cells and cell organelles has great importance. Furthermore the concentration and redox status of GSH as a(n oxidative) stress marker are used in almost all stress related studies [17]. Although widely accepted methods are available for the measurement of glutathione, the determined concentrations often vary between laboratories due to the different and usually incorrect pre-analytical handling of samples. The most common source of analytical inaccuracy is the autoxidation of GSH to GSSG during the (incorrect) sample preparation [18].

Not accidentally the most popular method for the determination of GSH is the GSH recycling assay [19]. GSH is oxidized by the reagent 5,5'-dithio-bis(2-nitrobenzoic acid) (DTNB) while the chromophore, 5'-thio-2-nitrobenzoic acid (TNB) and a mixed disulphide, GS-TNB are formed. The formed GS-TNB is regenerated to GSH by the externally added glutathione reductase (GR) on the expense of NADPH, or by directly in the reaction with the remaining GSH content of the assay mix. The rate of TNB production is proportional to the initial amount of GSH in the sample [19-21]. This way the total glutathione (GSH+GSSG) content of the sample is measured, unless a thiol masking reagent e.g.: N-ethylmaleimide (NEM) or vinylpyridine is added to the assay mix. These agents give us the possibility to measure the GSSG content of the samples even at low concentrations. The reduced glutathione content of the sample can be calculated by subtracting the amount of GSSG from that of total glutathione. The prevalence of the method can easily be explained by its rapid execution and relatively low cost. At the same time, no pre-analytical process that stabilizes the GSH is included by the protocol.

Bromo- and chlorobimanes are highly efficient labelling agents for cellular thiols, furthermore plasma membrane is freely permeable to them, and they form a fluorescent adduct specifically with GSH. Monochlorobimane $(\mathrm{mBCl})$ was found to form a fluorescent adduct with GSH more specifically than monobromobimane [22-24], thus it was used as a sensitive and specific probe to determine GSH in liver tissue, intact hepatocytes $[23,25]$ as well as in different cell organelles in both animal and plant cells [26, 27]. Monochlorobimane reacts specifically with thiol groups forming a highly fluorescent, cell-impermeable thioether, which can be separated by HPLC, equipped with a fluorescent detector [28]. Since $\mathrm{mBCl}$ reacts only with $\mathrm{GSH}$, the oxidized glutathione content of the samples has to be reduced by the addition of the reducing agent dithiothreitol (DTT) $[23,29,30]$. The redox state of the cellular, subcellular glutathione pool can be calculated by comparing the peak areas of the samples pre-treated or not with DTT. On the contrary to the DTNB method the bimane derivates are stable for several days in the dark [31]. However the $\mathrm{mBCl}$ method is more laborious and expensive.

In the present study we make an attempt to compare the above mentioned DTNB and mBCl-HPLC methods to choose the one that best suits for eco-toxicological and plant stress investigations. We also would like to give guidelines for proper sample preparation and pre-analytical handling. Since in eco-toxicological and plant stress studies, glutathione is most often measured in plant cells and different cell organelles such as mitochondria and endoplasmic reticulum the concentration of GSH was determined from Arabidopsis suspension cells, mitochondrial, microsomal and cyplasmic fractions isolated from control, $100 \mu \mathrm{M}$ BSO (DL-Buthionine-sulfoximine) and $100 \mu \mathrm{M}$ Cd treated Arabidopsis thaliana suspension cells.

\section{Materials and methods}

\subsection{Materials}

Murashige and Skoog medium, 2,4-dichlorophenoxyacetic acid (2,4-D), kinetin, EDTA, 4-morpholinepropanesulfonic acid (MOPS), Polyvinylpyrrolidone (PVP40), L-Cysteine, Glutathione S-Transferase (GST), 5,5-dithio-bis-(2-nitrobenzoic acid) (DTNB), Glutathione Reductase (GR), DL-Buthionine-sulfoximine (BSO) and glutathione (GSH) were obtained from SigmaAldrich. Monochlorobimane $(\mathrm{mBCl})$ was purchased from Invitrogen. $\mathrm{CdCl}_{2}$ and all other chemicals were of analytical or HPLC grade, and were purchased from Reanal, Hungary. Pierce Coomassie (Bradford) Protein Assay Kit was obtained from Thermo Scientific.

\subsection{Plant material}

Arabidopsis thaliana (ecotype Columbia) suspension cells were grown in culture medium containing $0.44 \%$ MS + Gamborg (Sigma-Aldrich); 3\% Sucrose; $0.24 \mu \mathrm{g} / \mathrm{ml}$ 2,4-dichlorophenoxyacetic acid; $0.014 \mu \mathrm{g} / \mathrm{ml}$ Kinetin; 
$4 \mathrm{mM}$ PBS $\left(\mathrm{K}_{2} \mathrm{HPO}_{4}, \mathrm{KH}_{2} \mathrm{PO}_{4}\right) ; \mathrm{pH} 5.8$ in a rotary shaker (120 rpm) at $22^{\circ} \mathrm{C}$, in the dark. Cells were subcultured weekly by a tenfold dilution.

\subsection{Cadmium and BSO treatments of Arabidopsis thaliana suspension cell cultures}

4-day old Arabidopsis thaliana cultures were used for the experiments. The required volume (less than $0.1 \mathrm{ml}$ in each case) of $\mathrm{CdCl}_{2}$ and $\mathrm{BSO}$ solutions were sterile filtrated by $0.22 \mu \mathrm{m}$ PTFE syringe filters, then added to the culture at the final concentration of $100 \mu \mathrm{M}$. Same volume of sterile water was added to control cells.

\subsection{Organelle isolation from Arabidopsis thaliana suspension cell cultures}

Known amount of freshly harvested, vacuum filtrated cells were homogenised in the appropriate isolation buffer by precooled Potter-Elvehjem homogenizer on ice. Four types of isolation buffers were used: 1. cell organelle isolation buffer ( $450 \mathrm{mM}$ sucrose, $1 \mathrm{mM}$ EDTA, $0.5 \mathrm{mM}$ EGTA, $15 \mathrm{mM}$ MOPS, 0.2\% (w/v) BSA, 0.6\% (w/v) PVP40, 1.5 mM L-Cysteine, $\mathrm{pH}$ 7.4), 2. cell organelle isolation buffer supplemented with $1 \mathrm{mM} \mathrm{mBCl}, 3$. 5-sulphosalicylic acid (SSA, 5\% (w/v)), 4. SSA (5\% (w/v)) supplemented with $1 \mathrm{mM} \mathrm{mBCl}$. All concentrations are final concentrations. The SSA containing buffers were used only for cell homogenate preparation, the cell organelle isolation buffers were used for organelle isolation and also for cell homogenate preparation. The lysate was centrifuged $\left(3,000 \mathrm{~g}, 20 \mathrm{~min}, 4^{\circ} \mathrm{C}\right)$ and the supernatant was gently harvested to determine the glutathione content of cell homogenate.

Different organelles were isolated from ca. $50 \mathrm{~g}$ of Arabidopsis cell suspension. The cells were disrupted in cold organelle isolation buffers by a precooled grinder. The grinded homogenate was centrifuged at $3,000 \mathrm{~g} 4^{\circ} \mathrm{C}$ for $15 \mathrm{~min}$. The supernatant was centrifuged at $17,000 \mathrm{~g}$, $4^{\circ} \mathrm{C}$ for $15 \mathrm{~min}$ to pellet the mitochondrial fraction, while the ER and cytoplasm remained in the supernatant. The latter ones separated by ultracentrifugation at $125,000 \mathrm{~g}$, $4^{\circ} \mathrm{C}$ for $60 \mathrm{~min}$ to pellet the ER. The mitochondrial fraction was washed with cell organelle isolation buffer and centrifuged at $3,000 \mathrm{~g}, 4^{\circ} \mathrm{C}$ for $10 \mathrm{~min}$, then the supernatant was centrifuged at $17,000 \mathrm{~g}, 4^{\circ} \mathrm{C}$ for $15 \mathrm{~min}$ to pellet the mitochondrial fraction.

The microsomal and the mitochondrial fractions were re-suspended in ice cold cell organelle isolation buffer to determine the glutathione content of the fractions.
The entire process was carried out as fast as possible using ice and precooled devices to minimise the degradation of GSH.

\subsection{Glutathione measurement by $\mathrm{mBCl}$ derivatisation and HPLC-fluorescent detection}

The GSH content of samples and standards were derivatized with $1 \mathrm{mM} \mathrm{mBCl}$ in the absence and presence of GST $(100 \mathrm{mU} / \mathrm{ml})$ in the indicated incubation media, at room temperature in the dark for $15 \mathrm{~min}$. The reaction was stopped by the addition of Trichloroacetic acid (TCA) at a final concentration of $10 \%(\mathrm{w} / \mathrm{v})$. To determine GSSG content, prior to derivatization $100 \mu 1$ of samples were mixed and incubated for $60 \mathrm{~min}$ in the dark, at room temperature with $10 \mu 150 \mathrm{mM}$ DTT to reduce GSSG to GSH.

The effect of isolation buffer and GST was also monitored by standards dissolved in 5\% (w/v) SSA and cell organelle isolation buffer. In case of SSA, prior to derivatization Triethanolamine (TEA) was added at a final concentration of $400 \mathrm{mM}$ to the samples and standards, to adjust the optimal $\mathrm{pH}$ for the conjugation with $\mathrm{mBCl}$.

Samples were centrifuged at $48,000 \mathrm{~g}, 4^{\circ} \mathrm{C}$ for $20 \mathrm{~min}$ to pellet the precipitated proteins. The separation of derivatized GSH was performed on a Teknokroma Mediterranea SEA18 C-18 column with $5 \mu \mathrm{m}$ beads and dimensions of 150 x $4.6 \mathrm{~mm}$, using Waters 2690 HPLC, followed by fluo$\operatorname{rescent}\left(\lambda_{\mathrm{EX}}: 395 \mathrm{~nm}, \lambda_{\mathrm{EM}}: 477 \mathrm{~nm}\right.$ ) detection (Waters 2475 ) with a 32.5 min protocol employing the linear gradient of $0.25 \%$ (v/v) aqueous acetic acid, $\mathrm{NaOH}, \mathrm{pH} 3.5$ as Solvent $\mathrm{A}$ and methanol as Solvent B. $0 \mathrm{~min}$ at $18 \%(\mathrm{v} / \mathrm{v})$ Solvent $\mathrm{B} ; 17.5 \mathrm{~min}$ at $18 \%(\mathrm{v} / \mathrm{v})$ Solvent $\mathrm{B} ; 20 \mathrm{~min}$ at $100 \%(\mathrm{v} / \mathrm{v})$ Solvent B; $27.5 \mathrm{~min}$ at $100 \%(\mathrm{v} / \mathrm{v})$ Solvent B; $28 \mathrm{~min}$ at $18 \%$ (v/v) Solvent B; 32.5 mint at 18\% (v/v) Solvent B, with $1 \mathrm{ml} / \mathrm{min}$ flow rate. Based on standards, the retention time of glutathione was $8.5 \mathrm{~min}$.

In case of cell homogenate, the glutathione content was normalized to the weight of freshly harvested, vacuum filtrated cells that was homogenised, in case of isolated cell organelles, the glutathione content was normalized to the protein content of each sample.

\subsection{Glutathione measurement by DTNB assay}

$100 \mu \mathrm{l}$ of reaction buffer $\left(45 \mathrm{mM} \mathrm{Na} \mathrm{PO}_{4}, 0.45 \mathrm{mM}\right.$ EDTA, $0.225 \mathrm{mM}$ DTNB, $0.3 \mathrm{mM}$ NADPH, $1.6 \mathrm{U} / \mathrm{ml} \mathrm{GR}$, $\mathrm{pH} 7.5$ ) was added to $50 \mu \mathrm{l}$ of sample or GSH standard on a 96-well plate. The reaction was followed by Thermo Scientific Multiskan ${ }^{\mathrm{TM}}$ GO Microplate Spectrophotometer for 5 minutes using $\lambda=405 \mathrm{~nm}$, at $25^{\circ} \mathrm{C}$ The initial 
2 minutes of the linear phase of TNB generation curve was used to quantify the glutathione content. In case of cell homogenate, the glutathione content was normalized to the weight of freshly harvested, vacuum filtrated cells that was homogenised and in case of isolated cell organelles, the glutathione content was normalized to the protein content of each sample.

\subsection{Other methods}

Protein concentration was determined by the Pierce Coomassie (Bradford) Protein Assay Kit with bovine serum albumin as a standard, according to the manufacturer's instructions. All data are expressed as means \pm S.D. Statistical analyses were performed by Student's t test.

The GSSG concentration was calculated by the following formula: ([Total glutathione]-[GSH])/2. The redox state was calculated as [GSH]/[GSSG+GSH]. SD was calculated based on the previously calculated redox-states.

\section{Results and discussion}

Our purpose was to get as close to real plant stress and eco-toxicological problems and investigations as it can, thus Arabidopsis thaliana suspension cells were treated with $100 \mu \mathrm{M}$ of $\mathrm{CdCl}_{2}$ and with $100 \mu \mathrm{M}$ of BSO (the inhibitor of $\gamma$-glutamyl-cysteinyl synthase). Cell homogenate, mitochondrial, cytosolic and microsomal fractions were prepared from the suspension cells and their GSH contents were determined by the two different methods. The spectrophotometric DTNB-GSH recycling assay is specific due to the application of glutathione reductase, it is rather quick and easy to perform, not surprising that it is rather preferred [19]. Thus it was chosen as the first method to determine the $\mathrm{GSH}$ content of control, $\mathrm{CdCl}_{2}$ and $\mathrm{BSO}$ treated Arabidopsis thaliana cell homogenates and organelles.

GSH is prone to auto-oxidation and decomposition on alkaline $\mathrm{pH}$. The acidification of the samples by the addition of SSA (at a final concentration of 5\%) can prevent or at least reduce the extent of auto-oxidation of GSH, since the thiol group is much more stable than its ionized thiolate form [18]. The disadvantage of this stabilization is that the addition of SSA precipitates proteins hence it makes the biological samples unsuitable for further organelle isolation [21]. Interestingly no difference could be observed in the glutathione content between the samples homogenized in 5\% SSA or organelle isolation buffer $(\mathrm{pH}=7.4)$, but significantly dropped glutathione level was found in case of organelle isolation buffer $+\mathrm{mBCl}$ (Fig. 1). The addition of $\mathrm{mBCl}$ to the organelle isolation buffer resulted in the formation of GSH-mBCl adducts. The formed adducts could not react in the DTNB-GSH recycling assay thus the measurable amount of GSH was decreased by the amount that entrapped by the adduct formation. On one hand it is worth to note that the GSH content of all samples was determined immediately after the homogenization that may explain the absence of any effect of acidification. On the other hand the acidification of the samples does not ensure full protection and the thiol group can also be oxidized during sample acidification [18]. Furthermore, it was found that all acids commonly used for acidification purpose, such as trichloroacetic, metaphosphoric, perchloric and sulfosalicylic acids, also oxidize GSH, but to different extents [32]. Hence our earlier statement that the crucial step of glutathione determination is the prevention of its auto-oxidation can be strengthened. It can be avoid by different thiol masking agents such as NEM, vinylpyridine and bimane [19, 22, 23, 33]. The problem with vinylpyridine is its slowly reacting nature furthermore it does not permeate cell membranes [34, 35]. Although NEM reacts quickly with GSH hence can prevent the oxidation of GSH, furthermore the formed GSH-NEM conjugate can be analysed by HPLC [36], but the relatively high limit of detection of the GSH-NEM conjugate by HPLC does not allow the determination of GSH from samples with low GSH levels [21]. Although bimanes react with GSH somewhat slower than NEM [18], the conjugation of GSH with bimane derivates can be accelerated by the use of GST enzymes [21-23]. Furthermore the bimane-GSH conjugates can be analysed by HPLC with fluorescence detection in a very sensitive manner $[21,23]$. Thus $\mathrm{mBCl}$ was used in our further experiments as a fluorophore and a masking agent to inhibit the auto-oxidation of GSH. The auto-oxidation of GSH was avoided by two different ways: 1 . by the addition of SSA. Since the formation of mBCl-GSH conjugate occurs at slightly alkaline $\mathrm{pH}$ (around 7.5-8), the samples should be neutralized before derivatisation with $\mathrm{mBCl}$. 0.4 M TEA was used for this purpose. 2. by the addition of $\mathrm{mBCl}$. After the homogenization $\mathrm{mBCl}$ was added to one half of the samples to prevent the auto-oxidation of GSH. Similar to the observations gained earlier in the case of DTNB-GSH recycling assay the homogenisation media has no influence on the measurable GSH content of the samples in the case of immediate conjugation of $\mathrm{GSH}$ with $\mathrm{mBCl}$ (Fig. 2).

The effect of SSA and the subsequent neutralization by TEA was investigated on the sensitivity of the method. 


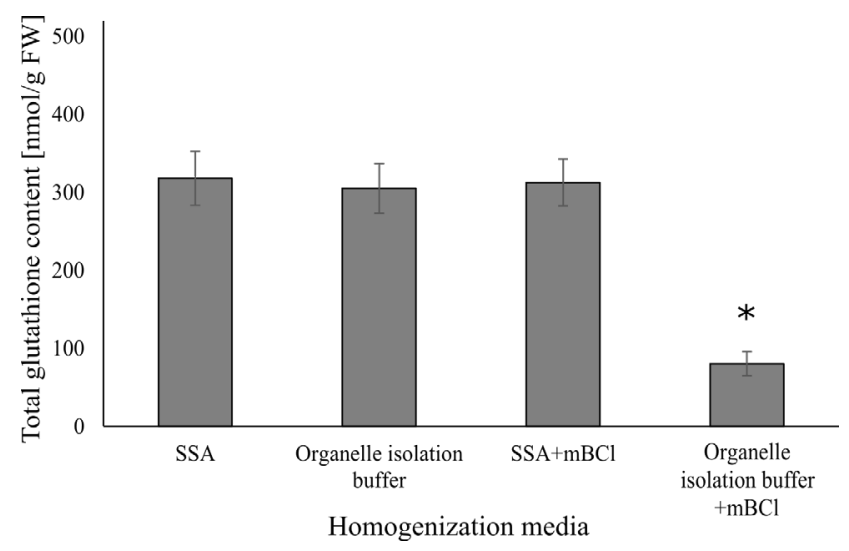

Fig. 1 The effect of the homogenization medium on the measured glutathione levels in Arabidopsis thaliana cells. Arabidopsis thaliana cells were harvested by vacuum filtration and homogenized by PotterElvehjem homogenizer in 5\% SSA or in organelle isolation buffer. Right after the homogenization $1 \mathrm{mM} \mathrm{mBCl}(\mathrm{mBCl})$ was added to one half of the homogenates and incubated for $15 \mathrm{~min}$ in the dark at room temperature. The glutathione content of all samples (with or without $\mathrm{mBCl}$ addition) was determined by DTNB-GSH recycling assay (see Materials and methods). The values represent means \pm SD from three different measurements. Asterisk represents significant difference with respect to all other samples $(\mathrm{p}<0.05)$.

GSH standards were dissolved in 5\% SSA and in organelle isolation buffer. The $\mathrm{pH}$ of GSH standard dissolved in SSA was adjusted to 7.4 by the addition of $0.4 \mathrm{M}$ TEA. $\mathrm{mBCl}$ was added to both standards and the fluorescence of GSH-mBCl conjugate was determined by HPLC with fluorescence detection. The addition of SSA significantly decreased the sensitivity of the method (Fig. 3). Since the $\mathrm{pH}$ of the solution was checked and adjusted to exactly $\mathrm{pH}=7.4$, the only reasonable explanation is the observed and published [32] oxidation of GSH by the added SSA.

As it was reported, the own GST activity of samples from animal tissues could not be enough for the complete conjugation of $\mathrm{GSH}$ by $\mathrm{mBCl}$ [21] thus the effect of externally added GST was also investigated on the sensitivity of the method. Our results strengthened the previous observation, the addition of GST definitely accelerated the formation of GSH-mBCl conjugate and significantly increased the sensitivity of the method (Fig. 3). The bimane conjugate formation makes the GSH unmeasurable for the DTNB-GSH recycling assay because of the conjugated tiol groups. Approximately $60 \%$ of the GSH content of the samples was conjugated by $\mathrm{mBCl}$ during the 15 min incubation time in the absence of GST (Fig. 1). This observation is in concordance with our previous results [21] and underlines the importance of the application of GST.

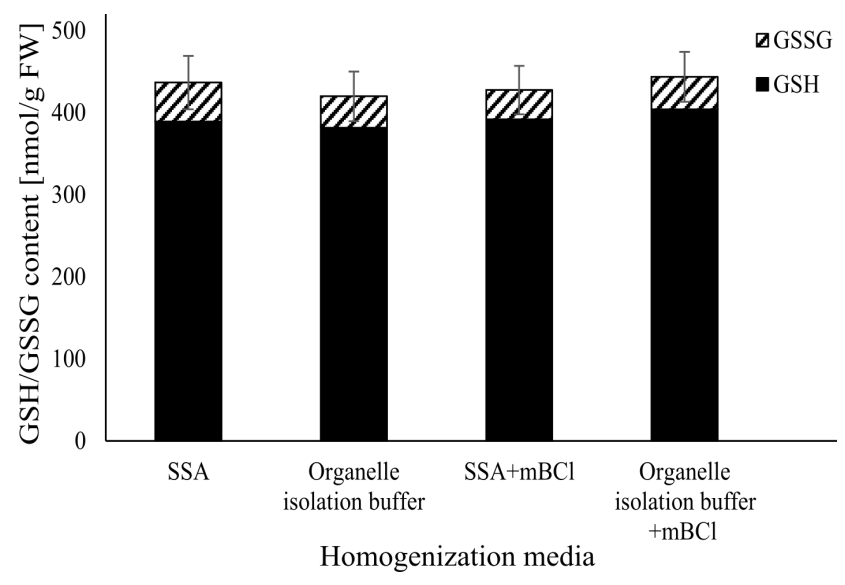

Fig. 2 The effect of the homogenization medium on the measured glutathione levels in Arabidopsis thaliana cells. Arabidopsis thaliana cells were harvested by vacuum filtration and homogenized by PotterElvehjem homogenizer in 5\% SSA or in organelle isolation buffer. Right after the homogenization $1 \mathrm{mM} \mathrm{mBCl}$ was added to one half of the homogenates and incubated for $15 \mathrm{~min}$ in the dark at room temperature. The glutathione content of all samples (with or without $\mathrm{mBCl}$ addition) was determined by HPLC after the proper sample preparation required by the method (see Materials and methods). The values represent means \pm SD from three different measurements.

The isolation of eco-toxicological and plant stress investigations relevant cell organelles takes several hours thus the protective role of $\mathrm{mBCl}$ may get more importance in the determination of GSH from these organelles. Cell organelles were prepared, in the absence and in presence of $\mathrm{mBCl}$ that was added to the cell homogenate right after the homogenization to investigate its potential protective role. The presence of $\mathrm{mBCl}$ in the organelle isolation buffer resulted in elevated measurable reduced GSH levels in each fraction (Fig. 4). This protective effect of $\mathrm{mBCl}$ became more significant by the time elapse. More marked effects can be observed in the case of endoplasmic reticulum and cytosol fractions (Fig. 4).

The isolation of these fractions takes approximately two times longer than the isolation of mitochondrial one. These results reinforce that auto-oxidation results in significant loss of reduced GSH [37] that can be prevented by the presence of $\mathrm{mBCl}$ in the organelle isolation buffer (from the beginning of the isolation of cell organelles). Additionally, this way the reduced GSH content of organelles can be determined much more precisely. However, it should be noted that this application of $\mathrm{mBCl}$ significantly elevates the cost of GSH determination, especially in case of cell organelles since it requires high volume of samples. Furthermore, the addition of $\mathrm{mBCl}$ to the organelle isolation buffer may interfere with other fluorescent 


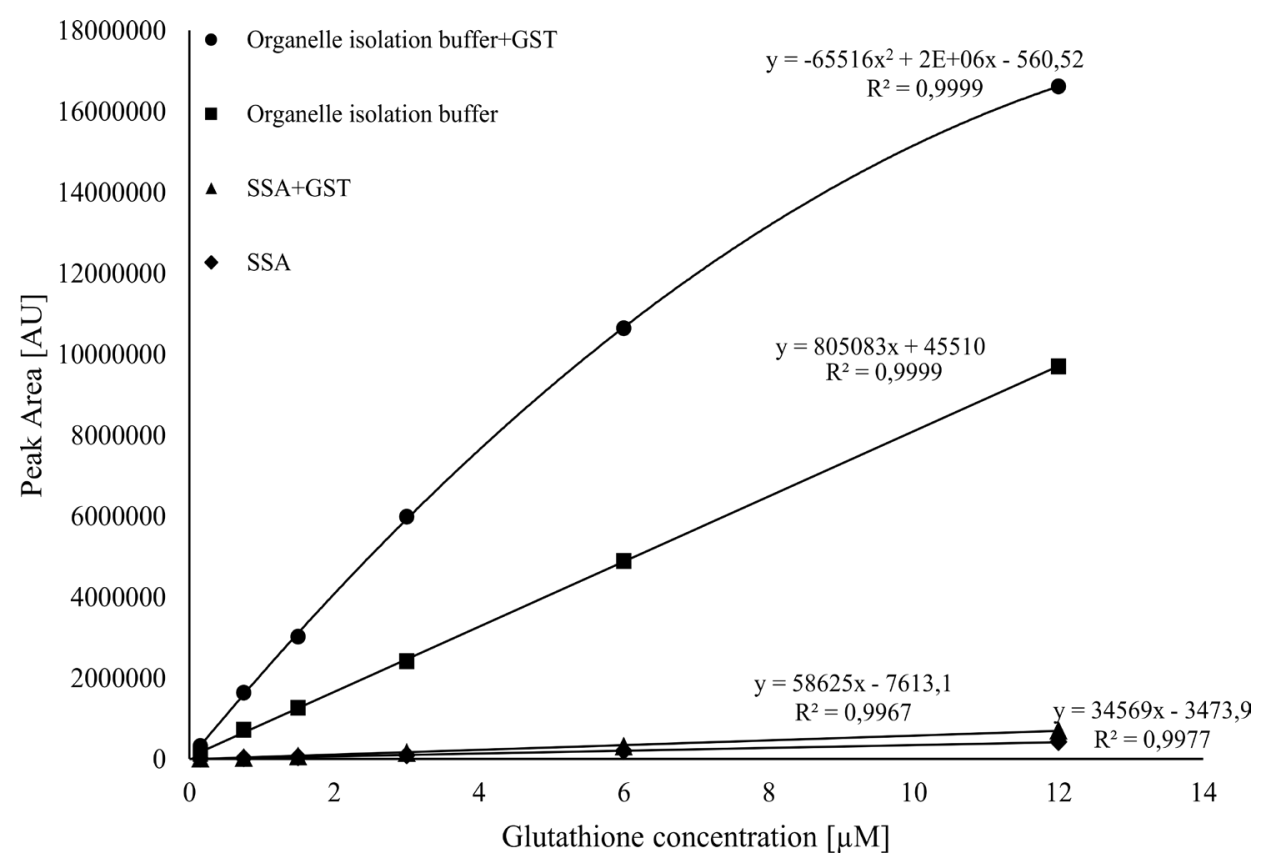

Fig. 3 Calibration curves of the HPLC method with different standard preparation methods. Glutathione was dissolved in 5\% SSA [triangle and diamond] or in organelle isolation buffer [circle and square]. To test the effect of the addition of GST on the mBCl derivatization, standards with [circle and triangle] or without GST [square and diamond] were prepared as described in Materials and methods. The data shown are means $\pm \operatorname{SD}(\mathrm{n}=3$ )
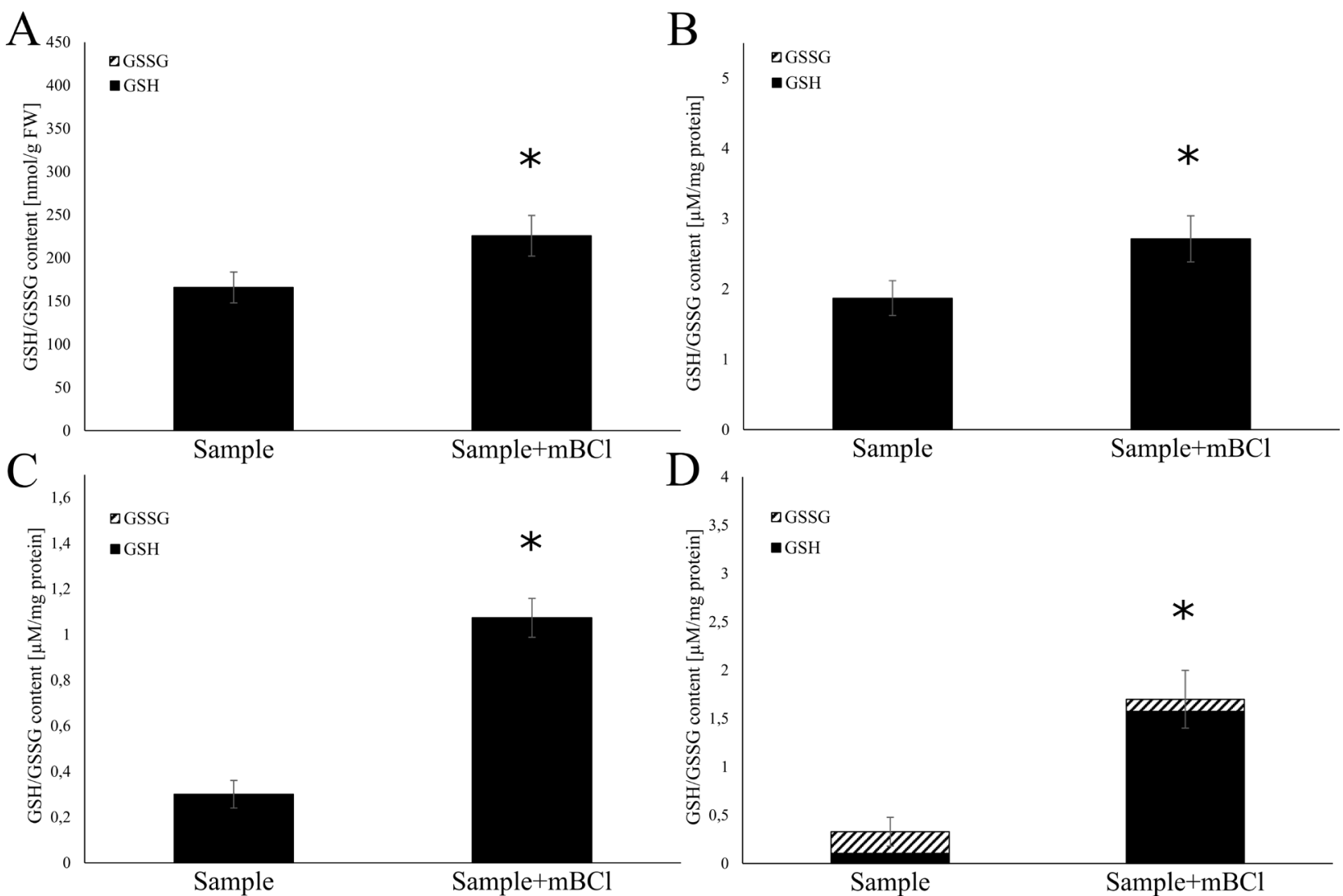

Fig. 4 The protective effect of monocholorbimane. Arabidopsis thaliana cells were harvested by vacuum filtration and organelles were isolated as described in Materials and methods. The glutathione content of the initial cell homogenate (A), mitochondria (B), ER (C) and cytoplasm (D)

was determined by HPLC (Sample). Parallel isolations were also carried out, in which $1 \mathrm{mM} \mathrm{mBCl}$ was added to the samples right after the homogenization of the cells (Sample $+\mathrm{mBCl}$ ). The data are expressed as means $\pm \mathrm{SD}$ from three different isolations. Asterisk represents significant difference with respect to sample $(\mathrm{p}<0.05)$ 
assays. Parallel the GSH content of same cell homogenates and cell organelles was also determined by the DTNB-GSH recycling method. The measurable GSH contents were lower in each sample than in the case of GSH-mBCl conjugates determined by HPLC with fluorescence detection (Fig. 1 vs Fig. 2, Fig. 5 and 6 panel A vs panel B), although the tendency of changes in GSH contents showed similar pattern.

To get closer to real eco-toxicological and plant stress investigations plant cell suspensions were shared into three groups and treated with the inhibitor of $\gamma$-glutaimyl-cysteinyl synthase inhibitor $\mathrm{BSO}$ or with $\mathrm{CdCl}_{2}$ or with equal volume of water. Cell homogenate, mitochondrial, cytosolic and microsomal fractions were prepared and the GSH content of them was determined by the two different methods. The cellular GSH content was followed for 24 hours (Fig. 5). Cd treatment caused an immediate decrease in the cellular GSH content (Fig. 5 panel A and B). Only the half of the initial GSH content could be measured after 2 hours of $\mathrm{Cd}$ treatment (Fig. 5 panel A and B). Since BSO inhibits the de novo biosynthesis of GSH caused a slower decrease in cellular GSH content (Fig. 5 panel A and B). It halves the cellular GSH content after 9 hours (Fig. 5 panel A and B).

At one half of the initial GSH content (after 2 hours of treatment for $\mathrm{CdCl}_{2}$ and after 9 hours for $\mathrm{BSO}$ ), cell organelle isolation was carried out. Interestingly in the case of endoplasmic reticulum and cytoplasm BSO treatment caused more severe GSH depletion (Fig. 6 panels B, E and C, F). The redox state of GSH showed similar pattern. BSO treatment caused more oxidized samples in case of $\mathrm{ER}$ and cytoplasm than the $\mathrm{CdCl}_{2}$ treatment (Fig. 6 panel B and C).

\section{Conclusion}

A common problem in plant stress and eco-toxicological investigations is the determination of the rate of oxidative stress and eco-toxicological injury. The level and redox status of glutathione can serve as a good indicator for both. Thus it can be unequivocally accepted that in plant stress and eco-toxicological investigations the determination of GSH and its redox status in plant cells and organelles has special importance.

Probably the most widely used method for the determination of GSH is the DTNB-GSH recycling assay. Its popularity can easily be explained by its rapid execution, high specificity due to the application of the enzyme glutathione reductase and relatively low cost. Although the GSH recycling DTNB assay is quite simple and rapid the stabilization of GSH by SSA acidification can be characterised by lower efficiency than the formation of $\mathrm{mBCl}-\mathrm{GSH}$ fluorescent conjugate. The addition of $\mathrm{mBCl}$ into the organelle isolation buffer could prevent the oxidation of GSH to GSSG during the isolation procedure. It is also worth to note that the addition of GST resulted in the significant acceleration of the formation of $\mathrm{mBCl}-\mathrm{GSH}$ fluorescent conjugate.
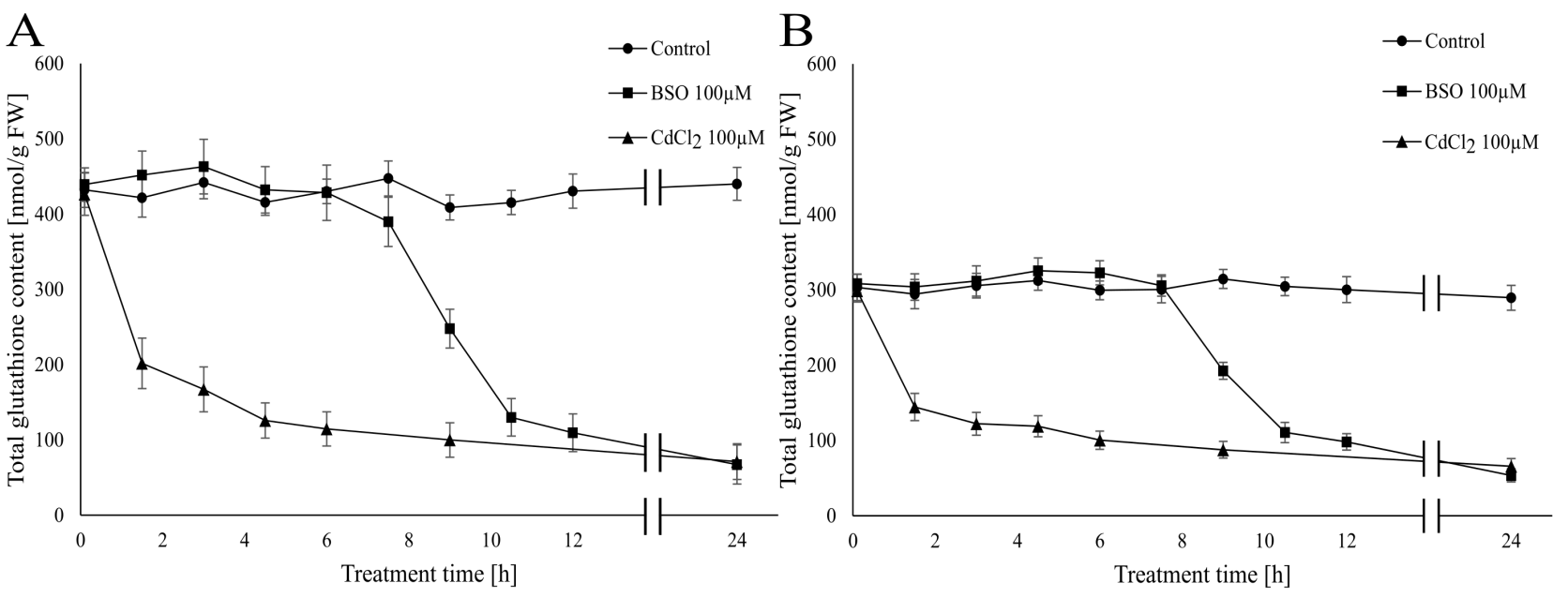

Fig. 5 Time course of glutathione depletion due to $100 \mu \mathrm{M}$ cadmium or BSO treatment. Arabidopsis thaliana cells were treated with $100 \mu \mathrm{M}$ CdCl ${ }_{2}$ [triangle] or $100 \mu \mathrm{M}$ BSO [square]. The cellular GSH content was followed by HPLC (A) or DTNB-GSH recycling assay (B). At indicated time points samples were taken and they were prepared for GSH measurement as described in Materials and methods. The data are expressed as means \pm SD from three different isolations. 

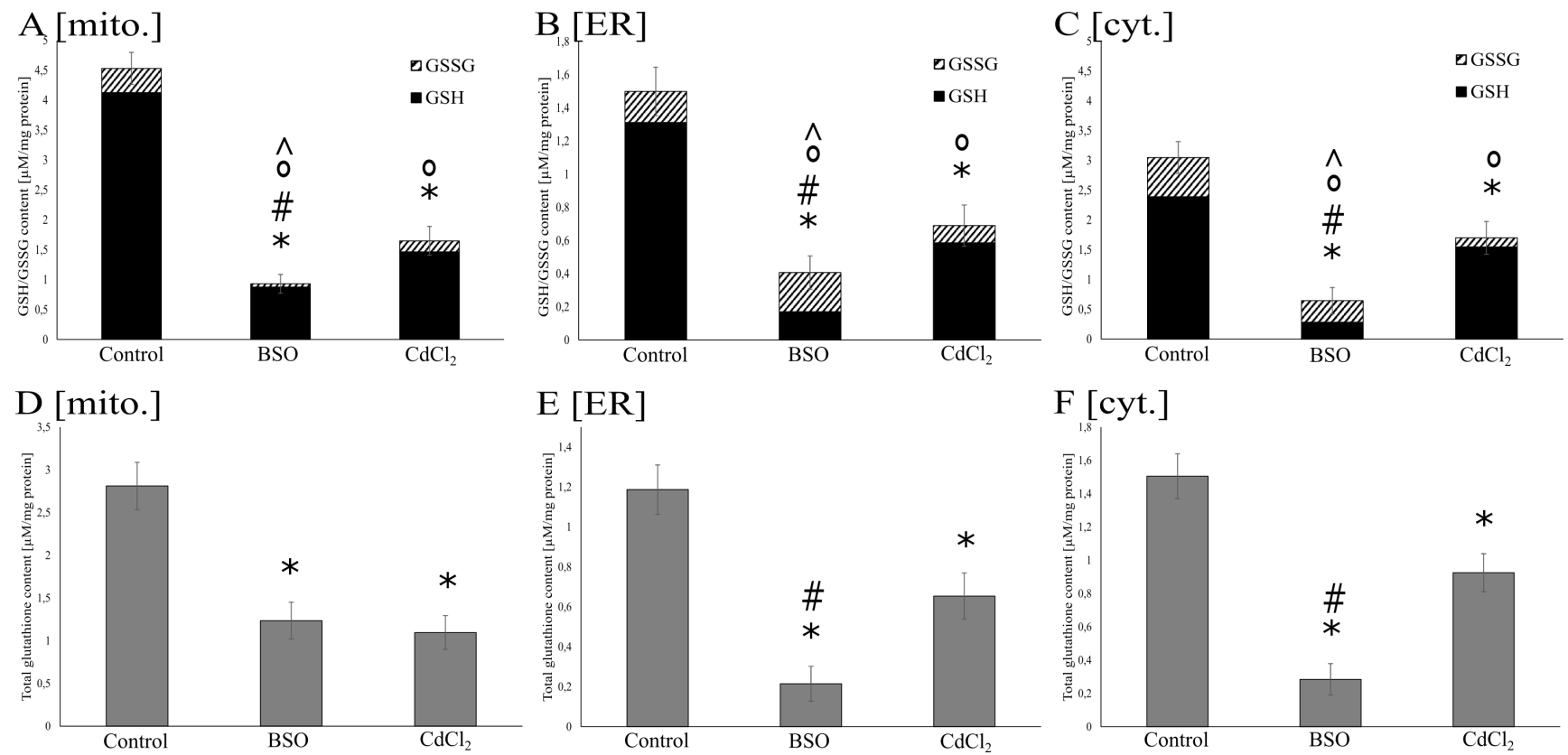

Fig. 6 Glutathione content of cadmium or BSO treated cell organelles. Arabidopsis thaliana cells were treated with $100 \mu \mathrm{M} \mathrm{CdCl}_{2}$ or $100 \mu \mathrm{M} \mathrm{BSO}$. After the initial glutathione content decreased by $50 \%$ (See Fig. 5.) the cells were harvested by vacuum filtration and organelles were isolated as described in Materials and methods. The glutathione content of mitochondria (A; D), ER (B; E) and cytoplasm $(\mathbf{C} ; \mathbf{F})$ was determined by HPLC (A-C) or DTNB (D-F) methods (see Materials and methods). $1 \mathrm{mM} \mathrm{mBCl}$ was added to the organelle isolation buffer right after the homogenization of the cells (A-C). The data shown are means \pm SD from three different treatments. * and \# represent significant differences in total glutathione content with respect to control $(*)$ and $\mathrm{CdCl}_{2}(\#) .{ }^{\circ}$ and ${ }^{\wedge}$ represent significant differences in glutathione redox state with respect to control $\left(^{\circ}\right)$ and $\mathrm{CdCl}_{2}\left({ }^{\wedge}\right)(\mathrm{p}<0.05)$.

On the base of our experiments the following method can be advised for the determination of GSH for eco-toxicological and plant stress investigations: the immediate addition of $\mathrm{mBCl}$ to the homogenisation buffer stabilizes the GSH for the whole cell organelle isolation. The following HPLC-fluorescence detection of the forming $\mathrm{mBCl}-\mathrm{GSH}$ fluorescent adduct ensures the sensitive and automated determination of GSH.

\section{References}

[1] Semane, B., Cuypers, A., Smeets, K., Van Belleghem, F., Horemans, N., Schat, H., Vangronsveld, J. "Cadmium responses in Arabidopsis thaliana: glutathione metabolism and antioxidative defence system", Physiologia Plantarum, 129(3), pp. 519-528, 2007.

https://doi.org/10.1111/j.1399-3054.2006.00822.x

[2] Korte, F. "Ecotoxicology of cadmium", Regulatory Toxicology and Pharmacology, 2(3), pp. 184-208, 1982 https://doi.org/10.1016/0273-2300(82)90013-7

[3] Das, P., Samantaray, S., Rout, G. R. "Studies on cadmium toxicity in plants: A review", Environmental Pollution, 98(1), pp. 29-36, 1997. https://doi.org/10.1016/S0269-7491(97)00110-3

[4] Singh, O. V., Labana, S., Pandey, G., Budhiraja, R., Jain, R. K. "Phytoremediation: an overview of metallic ion decontamination from soil", Applied Microbiology and Biotechnology, 61(5-6), pp. 405-412, 2003.

https://doi.org/10.1007/s00253-003-1244-4

\section{Acknowledgement}

This work was financially supported by National Scientific Research Fund grant (OTKA 123752). Tamás Lőrincz is a Gedeon Richter Plc Talentum fellowship recipient.

[5] Wang, X. F., Zhou, Q. X. "Ecotoxicological effects of cadmium on three ornamental plants", Chemosphere, 60(1), pp. 16-21, 2005. https://doi.org/10.1016/j.chemosphere.2004.12.031

[6] Garg, N., Aggarwal, N. "Effects of Interactions Between Cadmium and Lead on Growth, Nitrogen Fixation, Phytochelatin, and Glutathione Production in Mycorrhizal Cajanus cajan (L.) Millsp", Journal of Plant Growth Regulation, 30(3), pp. 286-300, 2011. https://oi.org/10.1007/s00344-010-9191-7

[7] Mendoza-Cózatl, D., Loza-Tavera, H., Hernández-Navarro, A., Moreno-Sánchez, R. "Sulfur assimilation and glutathione metabolism under cadmium stress in yeast, protists and plants", FEMS Microbiology Reviews, 29(4), pp. 653-671, 2005. https://doi.org/10.1016/j.femsre.2004.09.004

[8] Ben Ammar, W., Mediouni, C., Tray, B., Ghorbel, M. H., Jemal, F. "Glutathione and phytochelatin contents in tomato plants exposed to cadmium", Biologia Plantarum, 52(2), pp. 314-320, 2008. https://doi.org/10.1007/s10535-008-0065-9 
[9] Cobbett, C., Goldsbrough, P. "Phytochelatins and Metallothioneins: Roles in Heavy Metal Detoxification and Homeostasis", Annual Review of Plant Biology, 53(1), pp. 159-182, 2002.

https://doi.org/10.1146/annurev.arplant.53.100301.135154

[10] Cobbett, C. S. "Phytochelatins and their roles in heavy metal detoxification", Plant Physiology, 123(3), pp. 825-832, 2000. https://doi.org/10.1104/pp.123.3.825

[11] Grill, E., Winnacker, E. L., Zenk, M. H. "Phytochelatins: the principal heavy-metal complexing peptides of higher plants", Science, 230(4726), pp. 674-676, 1985.

https://doi.org/10.1126/science.230.4726.674

[12] Grill, E., Löffler, S., Winnacker, E. L., Zenk, M. H. "Phytochelatins, the heavy-metal-binding peptides of plants, are synthesized from glutathione by a specific gamma-glutamylcysteine dipeptidyl transpeptidase (phytochelatin synthase)", Proceedings of the National Academy of Sciences of the United States of America, 86(18), pp. $6838-6842,1989$.

https://doi.org/10.1073/pnas.86.18.6838

[13] Sun, Q., Wang, X. R., Ding, S. M., Yuan, X. F. "Effects of interactions between cadmium and zinc on phytochelatin and glutathione production in wheat (Triticum aestivum L.)", Environmental Toxicology, 20(2), pp. 195-201, 2005.

https://doi.org/10.1002/tox.20095

[14] Noctor, G., Gomez, L., Vanacker, H., Foyer, C. H. "Interactions between biosynthesis, compartmentation and transport in the control of glutathione homeostasis and signalling", Journal of Experimental Botany, 53(372), pp. 1283-304, 2002.

[15] Foyer, C. H., Noctor, G. "The Molecular Biology and Metabolism of Glutathione", In: Significance of Glutathione to Plant Adaptation to the Environment, Vol. 2, Springer Netherlands, 2001, pp. 27-56. https://doi.org/10.1007/0-306-47644-4_3

[16] Noctor, G., Foyer, C. H. "ASCORBATE AND GLUTATHIONE: Keeping Active Oxygen Under Control", Annual Review of Plant Physiology and Plant Molecular Biology, 49, pp. 249-279, 1998. https://doi.org/10.1146/annurev.arplant.49.1.249

[17] Czobor, Á., Hajdinák, P., Szarka, A. "Rapid ascorbate response to bacterial elicitor treatment in Arabidopsis thaliana cells", Acta Physiologiae Plantarum, 39(2), pp. 62-77, 2017.

https://doi.org/10.1007/s11738-017-2365-1

[18] Giustarini, D., Tsikas, D., Colombo, G., Milzani, A., DalleDonne, I., Fanti, P., Rossi, R. "Pitfalls in the analysis of the physiological antioxidant glutathione (GSH) and its disulfide (GSSG) in biological samples: An elephant in the room", Journal of Chromatography B: Analytical Technologies in the Biomedical and Life Sciences, 1019, pp. 21-28, 2016.

https://doi.org/10.1016/j.jchromb.2016.02.015

[19] Tietze, F. "Enzymic method for quantitative determination of nanogram amounts of total and oxidized glutathione: applications to mammalian blood and other tissues", Analytical Biochemistry, 27(3), pp. 502-522, 1969.

https://doi.org/10.1016/0003-2697(69)90064-5

[20] Rahman, I., Kode, A., Biswas, S. "Assay for quantitative determination of glutathione and glutathione disulfide levels using enzymatic recycling method," Nature Protocols, 1(6), pp. 3159-3165, 2006.

https://doi.org/10.1038/nprot.2006.378
[21] Lörincz, T., Szarka, A. "The determination of hepatic glutathione at tissue and subcellular level", Journal of Pharmacological and Toxicological Methods, 88, pp. 32-39, 2017.

https://doi.org/10.1016/j.vascn.2017.05.004

[22] Rice, G. C., Bump, E. A., Shrieve, D. C., Lee, W. L., Kovacs, M. K. "Quantitative Analysis of Cellular Glutathione by Flow Cytometry Utilizing Monochlorobimane: Some Applications to Radiation and Drug Resistance in Vitro and in Vivo", Cancer Research, 46, pp. 6105-6110, 1986.

[23] Fernández-Checa, J., Kaplowitz, N. "The use of monochlorobimane to determine hepatic GSH levels and synthesis", Analytical Biochemistry, 190(2), pp. 212-219, 1990. https://doi.org/10.1016/0003-2697(90)90183-A

[24] Čapek, J., Hauschke, M., Brůčková, L., Roušar, T. "Comparison of glutathione levels measured using optimized monochlorobimane assay with those from ortho-phthalaldehyde assay in intact cells", Journal of Pharmacological and Toxicological Methods, 88(Pt 1), pp. $40-45,2017$. https://doi.org/10.1016/j.vascn.2017.06.001

[25] Lörincz, T., Jemnitz, K., Kardon, T., Mandl, J., Szarka, A. "Ferroptosis is Involved in Acetaminophen Induced Cell Death", Pathology and Oncology Research, 21(4), pp. 1115-1121, 2015. https://doi.org/10.1007/s12253-015-9946-3

[26] Szarka, A. "Quantitative data on the contribution of GSH and Complex II dependent ascorbate recycling in plant mitochondria." Acta Physiologiae Plantarum, 35(11), pp. 3245-3250, 2013. https://doi.org/10.1007/s11738-013-1359-x

[27] Nagy, G., Szarka, A., Lotz, G., Dóczi, J., Wunderlich, L., Kiss, A., Jemnitz, Zs., Veres, G., Bánhegyi, Zs., Schaff, B., Sümegi, J., Mandl, J. "BGP-15 inhibits caspase-independent programmed cell death in acetaminophen-induced liver injury", Toxicology and Applied Pharmacology, 243(1), pp. 96-103, 2010. https://doi.org/10.1016/j.taap.2009.11.017

[28] Meyer, A. J., May, M. J., Fricker, M. "Quantitative in vivo measurement of glutathione in Arabidopsis cells", Plant Journal, 27(1), pp. 67-78, 2001. https://doi.org/10.1046/j.1365-313X.2001.01071.x

[29] Zsigmond, L., Tomasskovics, B., Deák, V., Rigó, G., Szabados, L., Bánhegyi, G., Szarka, A. "Enhanced activity of galactono-1,4-lactone dehydrogenase and ascorbate-glutathione cycle in mitochondria from complex III deficient Arabidopsis", Plant Physiology and Biochemistry, 49(8), pp. 809-815, 2011. https://doi.org/10.1016/j.plaphy.2011.04.013

[30] Nagy, G., Kardon, T., Wunderlich, L., Szarka, A., Kiss, A., Schaff, Z., Bánhegyi, G., Mandl, J. "Acetaminophen induces ER dependent signaling in mouse liver", Archives of Biochemistry and Biophysics, 459(2), pp. 273-279, 2007. https://doi.org/10.1016/j.abb.2006.11.021

[31] Noctor, G., Queval, G., Mhamdi, A., Chaouch, S., Foyer, C. H. "Glutathione", The Arabidopsis Book, 9, pp. 1-32, 2011. https://doi.org/10.1199/tab.0142

[32] Rossi, R., Milzani, A., Dalle-Donne, I., Giustarini, D., Lusini, L., Colombo, R., Di Simplicio, P. "Blood glutathione disulfide: in vivo factor or in vitro artifact?", Clinical Chemistry, 48(5), pp. 742-753, 2002. 
[33] Griffith, O. W. "Determination of glutathione and glutathione disulfide using glutathione reductase and 2-vinylpyridine", Analytical Biochemistry, 106(1), pp. 207-212, 1980. https://doi.org/10.1016/0003-2697(80)90139-6

[34] Lindorff-Larsen, K., Winther, J. R. "Thiol Alkylation below Neutral pH", Analytical Biochemistry, 286(2), pp. 308-310, 2000. https://doi.org/10.1006/abio.2000.4807

[35] Gorin, G., Martic, P. A., Doughty, G. "Kinetics of the reaction of $\mathrm{N}$-ethylmaleimide with cysteine and some congeners", Archives of Biochemistry and Biophysics, 115(3), pp. 593-597, 1966.
[36] Giustarini, D., Dalle-Donne, I., Milzani, A., Fanti, P., Rossi,R. "Analysis of GSH and GSSG after derivatization with N-ethylmaleimide", Nature Protocols, 8(9), pp. 1660-1669, 2013. https://doi.org/10.1038/nprot.2013.095

[37] Srivastava, S. K., Beutler, E. "Oxidized glutathione levels in erythrocytes of glucose-6-phosphate-dehydrogenase-deficient subjects", The Lancet, 292(7558), pp. 23-24, 1968.

https://doi.org/10.1016/S0140-6736(68)92892-4 